\title{
Powołanie Narodowego Instytutu Onkologii i Hematologii — warunek konieczny do skutecznej walki z rakiem w Polsce
}

\author{
Witold A. Zatoński
}

\section{Establishing of the National Institute of Oncology and Hematology - necessary for successful cancer control in Poland}

Słowa kluczowe: Narodowy Instytut Onkologii i Hematologii, „cancer control in all policies", prewencja pierwotna raka płuca, badania przesiewowe w kierunku nowotworów szyjki macicy i nowotworów piersi

Key words: National Institute of Oncology and Hematology, cancer control in all policies, lung cancer primary prevention, cervical cancer and breast cancer screening

NOWOTWORY Journal of Oncology 2013; 63, 5: 375-381

Onkologia w Polsce jest w bardzo ważnym momencie swojego rozwoju. Po wielu latach narastania zadłużenia Centrum Onkologii w Warszawie, oraz dezintegracji pracy tak wewnątrz Instytutu w Warszawie, jak i dezintegracji współpracy pomiędzy jego Oddziałami, doszło do przełomu. W 2011 roku Prof. Krzysztof Warzocha, Dyrektor Instytutu Hematologii, został desygnowany przez Ministra Zdrowia do uporządkowania działalności i finansów Centrum Onkologii w Warszawie. Prof. Warzocha przeprowadził w krótkim czasie konieczne, często bolesne reformy. Zreformowano zasady pracy i działania zakładów klinicznych i ambulatoriów. Skokowo wzrosła realizacja umów z Narodowym Funduszem Zdrowia. W ciągu roku zlikwidowany został dług warszawskiego Centrum Onkologii. Stało się to także dzięki solidarnej pomocy Oddziałów Instytutu w Gliwicach i Krakowie. Wszystkie trzy Oddziały zakończyły rok 2012 dodatnim bilansem ekonomicznym. Dyrektor doprowadził także do uporządkowania i umocnienia współpracy pomiędzy Oddziałami Instytutu. Jednym ze znaków powrotu do harmonijnego współdziałania Oddziałów było wspólne wystąpienie Dyrekcji i Rad Naukowych Instytutu Hematologii i Instytutu Onkologii w Warszawie z Oddziałami w Gliwicach i Krakowie w czerwcu 2013 roku z wnioskiem do Ministerstwa Zdrowia o powołanie Narodowego Instytutu Onkologii i Hematologii.

Kolejnym krokiem integrującym środowisko onkologiczne w Polsce są właśnie prowadzone, z inicjatywy dyrektorów instytucji onkologicznych, działania na rzecz stworzenia Rady Dyrektorów Wielospecjalistycznych Publicznych Centrów Onkologii.

Oczywiście to dopiero początek drogi. Środowisku onkologii potrzebna jest konsolidacja i wypracowanie wspólnego, kompromisowego stanowiska w sprawie dalszego rozwoju onkologii w Polsce. Potrzebna jest publiczna debata, nie tylko onkologów. Warto jednak spróbować zakreślić jej ramy. Należy przypomnieć, że w Polsce istnieją historycznie ugruntowane struktury, koncepcje i strategie działań onkologii i hematologii. Potrzebna jest kontynuacja tego, co jest dziedzictwem Marii Skłodowskiej-Curie, Franciszka Łukaszczyka, Tadeusza Koszarowskiego, Witolda Rudowskiego.

Od 1975 roku, na zlecenie rządu, Centrum Onkologii w Warszawie wraz z Oddziałami w Gliwicach i Krakowie realizowały we współpracy z siecią onkologiczną i wszystkimi zainteresowanymi instytucjami naukowymi w Polsce jeden

Zakład Epidemiologii i Prewencji Nowotworów

Centrum Onkologii - Instytut im. Marii Skłodowskiej-Curie w Warszawie 
z pierwszych w Europie, nie tylko Centralnej, narodowych programów walki z rakiem, tak zwany PR-7. Program ten stworzony i prowadzony był przez Prof. Tadeusza Koszarowskiego'. Także obecnie prowadzony Narodowy Program Walki z Rakiem (2006-2015) i jego koncepcja zostały stworzone przez Centrum Onkologii i regionalne ośrodki onkologiczne w Polsce.

Wszystkie te istniejące struktury organizacji onkologii oraz koncepcje wymagają rozbudowy, ulepszenia, ale i kontynuacji. Jednak na pewno niepotrzebne jest mnożenie mglistych pomysłów na nowe eksperymenty i kolejne inicjatywy. Dyskusja na temat przyszłości polskiej onkologii powinna być prowadzona fair i nie personalizowana. Stwierdzenie, że, Instytut Onkologii [...] w rankingu polskich instytucji naukowych ma niską pozycję" (Medical Tribune, nr 13) i dlatego nie może ogrywać wiodącej roli w rozwoju onkologii w Polsce jest, najdelikatniej mówiąc, grubym nadużyciem.

Nieskromnie przypomnę, że liczba cytowań samego kierowanego przeze mnie Zakładu Epidemiologii i Prewencji Nowotworów, Centrum Onkologii w Warszawie, według bazy ISI Web of Science wynosi 13053 (dane z 22 sierpnia 2013 r.), a tzw. współczynnik Hirscha wynosi 50, czyli jest na poziomie, którego nie powstydziłby się niejeden uniwersytet medyczny w Polsce (patrz Polityka nr 22 (2909), 27.05.-4.06.2013). Przypomnę też, że spadek zachorowań na raka płuca u mężczyzn w Polsce o $30 \%$ w ostatnim dwudziestoleciu niewątpliwie należy do największych osiągnięć mojego Zakładu i polskiej onkologii (ryc. 1). Zapobieganie zachorowaniom na raka płuca w Polsce - prewencja pierwotna - zostało uznane za wzorcowe na świecie ${ }^{2}$. Dlatego mój Zakład został desygnowany przez Dyrektora Generalnego Światowej Organizacji Zdrowia na Ośrodek Współpracy z WHO.

Przy wszystkich zastrzeżeniach, które można mieć do warszawskiego Centrum Onkologii, nie wydaje się, żeby istniała w Polsce lepiej przygotowana merytorycznie, naukowo i kadrowo placówka, która mogłaby skutecznie pełnić rolę Narodowego Centrum.

W drugiej części mojego przesłania chciałbym powiedzieć kilka słów o epidemiologii, zapobieganiu zachorowań na nowotwory (prewencji pierwotnej), oraz ich wczesnej, populacyjnej diagnostyce (prewencji wtórnej) — czyli o tych polach, za które obecnie, w wyniku reorganizacji przeprowadzonej przez Dyrektora K. Warzochę, odpowiada mój Zakład.

Chciałbym przypomnieć, że nowotwory złośliwe w najbliższych dziesięcioleciach będą naszym najpoważniejszym

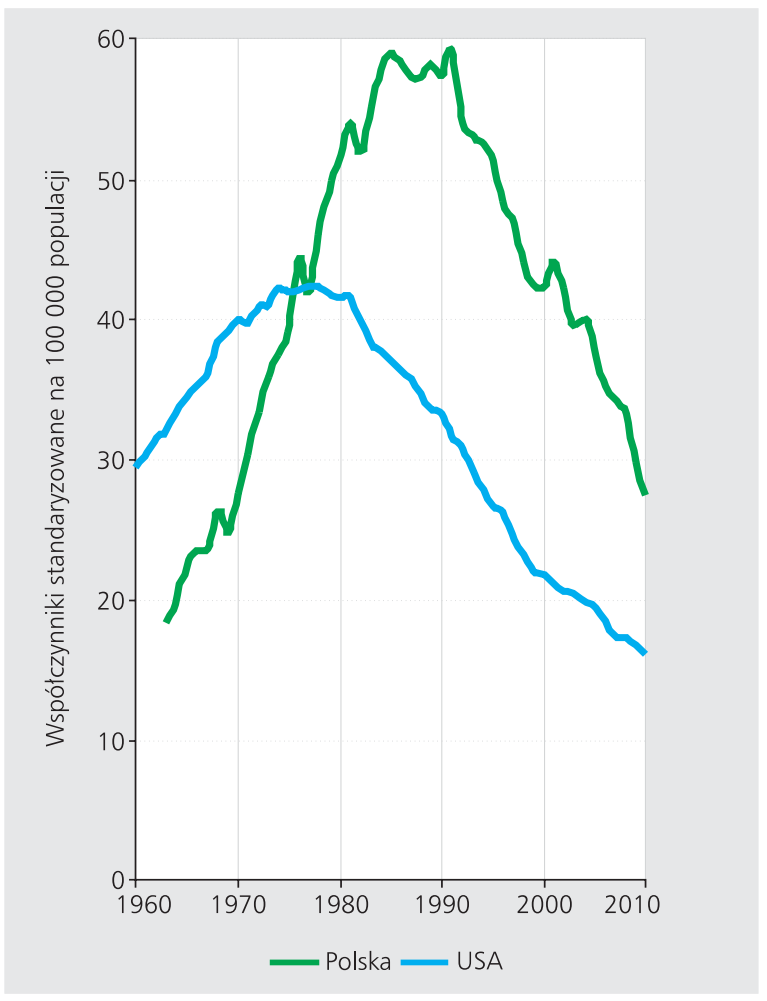

Rycina 1. Umieralność z powodu nowotworów płuca w Polsce i USA, mężczyźni 35-54, 1960-2010 [standaryzowane (na populację świata) współczynniki umieralności na 100000 populacji]

wyzwaniem zdrowotnym; pierwszą przyczyną przedwcześnie przerywającą ludzkie życie ${ }^{3}$. Już teraz prawie trzy razy więcej kobiet przed 65 rokiem życia umiera z powodu nowotworów złośliwych niż z powodu chorób układu sercowo-naczyniowego i zjawisko to będzie się w najbliższych dekadach stale nasilało, także u mężczyzn (ryc. 2). W drugiej dekadzie XXI wieku w Polsce rozpoznaje się corocznie co najmniej 150000 nowych przypadków nowotworowych. Ten gwałtowny przyrost dobrze ilustruje przykład raka piersi u kobiet. W 2000 roku rozpoznano około 11000 nowych przypadków raka piersi, a liczba ta wzrosła do prawie 16000 w 2012 roku. Szacuje się, że liczba kobiet żyjących z rozpoznaniem nowotworu piersi wynosi dzisiaj co najmniej 55 000-60 000.

To ogromne wyzwanie wymaga dalszej konsolidacji programu walki z rakiem w Polsce oraz istnienia instytucji państwowej odpowiedzialnej za jego realizację. Program musi obejmować wszystkie dziedziny walki z rakiem zgodnie z rekomendacjami WHO i doświadczeniami wielu krajów Unii Europejskiej. Musi również obejmować wszystkie sfery

\footnotetext{
${ }^{1}$ Przerwany około 1990 r. na następne 15 lat.

${ }^{2}$ Mówił o tym także, za co mu dziękuję, Profesor Jacek Jassem, na spotkaniu Polskiego Towarzystwa Onkologicznego w Warszawie 30 listopada 2012 r. z okazji 80-lecia Powstania Instytutu Radowego, wręczając mi zaszczytny tytuł Honorowego Członka PTO.

${ }^{3}$ Zatoński W. i wsp. Closing the health gap in European Union. Cancer Center and Institute, Warsaw 2008; Wyrównanie różnic w zdrowiu między krajami Unii Europejskiej. Centrum Onkologii — Instytut im. Marii Skłodowskiej-Curie, Warszawa, 2011; www.hem.pl.

Zatonski WA, Bhala N. Changing trends of diseases in Eastern Europe: Closing the gap. Public Health 2012; 126: $248-252$.

Zatoński W. Zdrowie — szczęście Polski i jej obywateli (Health — the happiness of Poland and its citizens). W: Polska gospodarka rozwój regionów. Polish economy - development of regions. Warszawa 2012: 216-225.
} 


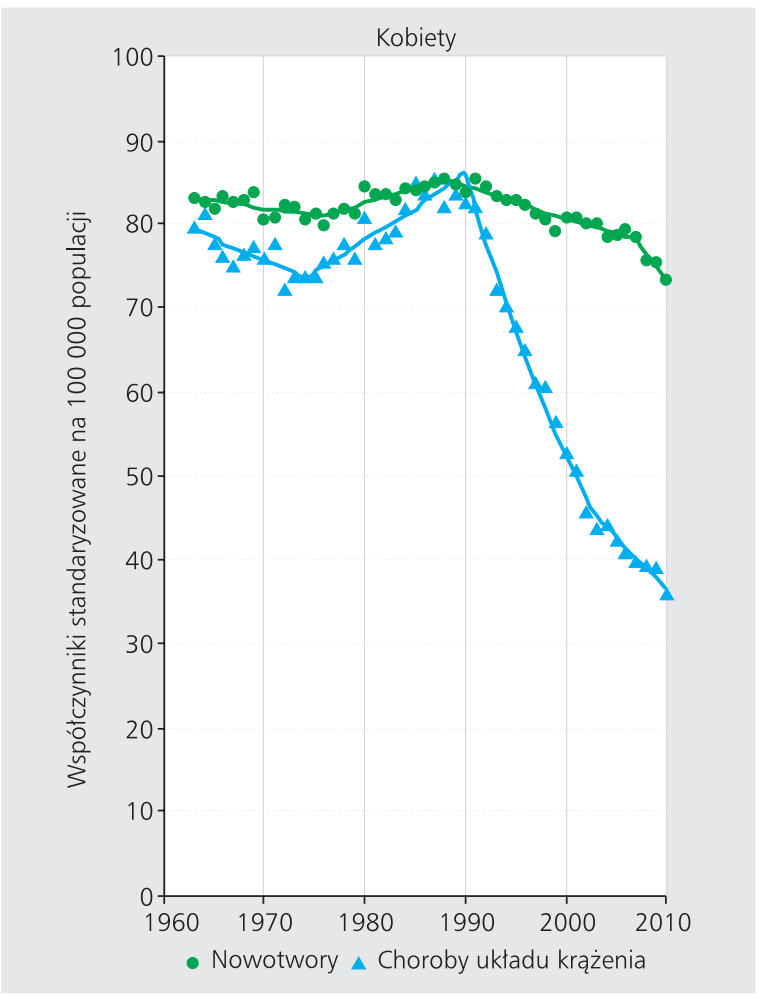

Rycina 2. Umieralność z powodu nowotworów i chorób układu krążenia w Polsce, 0-64 [standaryzowane (na populację Europy) współczynniki umieralności na 100000 populacji]

działań państwa (tzw. 'Cancer Control in All Policies'). Jeszcze raz chciałbym to podkreślić — walka z rakiem to nie tylko leczenie, szpitale, leki, lekarze. Kontrolowanie nowotworów wymaga różnorodnych działań, obejmujących budowanie kompetencji w zakresie nowotworów całego społeczeństwa (tzw., alfabetyzacja nowotworowa"), zapobieganie zachorowaniom na nowotwory (np. poprzez eliminację palenia czy poprzez szczepienia przeciw HPV), wczesną diagnostykę „zdrowej" populacji (skryning) zapobiegającą zgonom nowotworowym w lokalizacjach w których jest to możliwe (np. rak szyjki macicy czy nowotwory złośliwe jelita grubego, a także nowotwory piersi), a także oczywiście leczenie kliniczne. Ważnym elementem walki z rakiem są też działania dla poprawy jakości życia pacjentów terminalnych.

Dopiero taki wielopłaszczyznowy program może doprowadzić do realizacji postulatu $\mathrm{WHO}$, aby narodowe programy walki z rakiem osiągnęły to co jest możliwe przy obecnym stanie wiedzy; zapobiegnięcie 1/3 zachorowań na nowotwory złośliwe, wczesne rozpoznanie i skuteczne wyleczenie $1 / 3$ zachorowań na nowotwory złośliwe, oraz poprawienie jakości życia pozostałej 1/3 chorych na nowotwory złośliwe, czyli pacjentów terminalnych.

W ostatniej części mojej wypowiedzi chciałbym przedstawić kilka uwag dotyczących skryningu populacyjnego (prewencji wtórnej). Przez całą dekadę lat 90. środowisko onkologów zabiegało o powrót do rozpoczętego w 1975 roku programu rządowego walki z rakiem (PR-7), którego realizacja została przerwana około 1990 roku. Efektem tych starań jest Narodowy Program Zwalczania Chorób Nowotworowych (NPZChN) na lata 2006-2015, który został przygotowany przez środowisko onkologów polskich. Jego koncepcja została stworzona przez grupę inicjatywną (w której miałem przyjemność uczestniczyć) na czele z Profesorem Janem Steffenem, ówczesnym dyrektorem Centrum Onkologii w Warszawie, we współpracy z całą społecznością onkologów, naukowców oraz organizacji onkologicznych. Dokument został przekazany politykom i przyjęty w 2005 roku i jest obecnie realizowany przez Państwo Polskie. Jego najważniejszym elementem jest skryning populacyjny który na obecnym etapie dotyczy nowotworów złośliwych szyjki macicy u kobiet w grupie wieku 25-59 lat, oraz nowotworów złośliwych piersi u kobiet w grupie wieku 50-69 lat.

Warto przy tym przypomnieć, że taki program do dzisiaj jeszcze nie został wprowadzony w niektórych krajach europejskich, np. w Niemczech. Jedynym miernikiem sukcesu skryningu populacyjnego jest udokumentowany spadek współczynników umieralności w zakresie, w którym jest on prowadzony. Pięcioletnie przeżycia w monitorowaniu skryningu populacyjnego nie są dobrym miernikiem postępu tej interwencji, bo w znacznym stopniu długość przeżyć jest uwarunkowana stadium rozpoznania schorzenia (im wcześniej rozpoznane schorzenie, tym dłuższe „naturalne” przeżycie) ${ }^{4}$. Przygotowanie i prowadzenie w Polsce populacyjnego skryningu tych dwóch lokalizacji nowotworowych rozpoczęto w 2006 roku. To znaczy, że od jego stopniowego wprowadzenia upłynęło zaledwie kilka lat, a pełnych efektów populacyjnych należy się spodziewać w latach 2020-20305.

Jednak już obecnie można zaobserwować znaczące zmiany obrazu nowotworów wynikające z wprowadzenia skryningu.

1. Populacyjny skryning raka szyjki macicy doprowadził do konsolidacji istotnego spadku współczynników umieralności z powodu nowotworów szyjki macicy we wszystkich grupach wiekowych i we wszystkich regionach Polski (ryc. 3 i 4). Poziom umieralności jest stale wyższy niż w krajach zachodnich Unii, ale, co warto też przypomnieć, niższy niż w wielu sąsiednich krajach, np. krajach

4Patrz: Autier P, Boniol M, Hery C, Masuyer E, Ferlay J. Cancer survival statistics should be viewed with caution. Lancet Oncol 2007; 8: 1129-1138.

${ }^{5} Z$ drugiej strony obserwuje się też „niecierpliwość" różnych grup, które chciałyby natychmiastowych, tylko pozytywnych wyników podjętej interwencji.

Nowotwory nie są chorobą sezonową (jak grypa) i zmiany obrazu epidemiologicznego można oczekiwać najszybciej w okresie za 10-15 lat, nie z roku na rok. 
bałtyckich. Największym wyzwaniem w kontroli raka szyjki macicy w Polsce jest niewielki udział w skryningu gorzej wykształconych i słabiej sytuowanych kobiet, często mieszkanek małych miejscowości i wsi (ryc. 5). Konieczne jest stworzenie programów które doprowadzą do zmniejszenia liczby kobiet, które nigdy nie uczestniczyły w badaniu (obecnie około 20\% w grupie wieku 25-59 lat).

2. Wprowadzenie nowych technik wczesnej diagnostyki nowotworów piersi u kobiet (zakup nowoczesnych urządzeń mammograficznych charakteryzujących się dużą czułością i swoistością, wzrost liczby mammografów i liczony w setki tysięcy wzrost liczby wykonywanych mammografii w populacji zdrowych kobiet) doprowadziło do bardzo istotnych zmian obrazu nowotworów piersi u kobiet w Polsce. Bardzo istotnie wzrosła liczba wcześnie rozpoznawanych nowotworów piersi — w ostatniej dekadzie z 11000 do prawie 16000 (ryc. 6). Obserwuje się także objawy zatrzymania obserwowanego od dziesięcioleci wzrostu umieralności z powodu tego schorzenia (ryc. 7), a nawet pierwsze oznaki spadku umieralności; a w populacji przed 50 r.ż. wystąpił już spadek umieralności o prawie 40\% (ryc. 8). Zjawisko spadku umieralności z powodu nowotworów piersi będzie najprawdopodobniej utrwalać się w Polsce w najbliższym dziesięcioleciu. Niestety wskaźniki epidemiologiczne

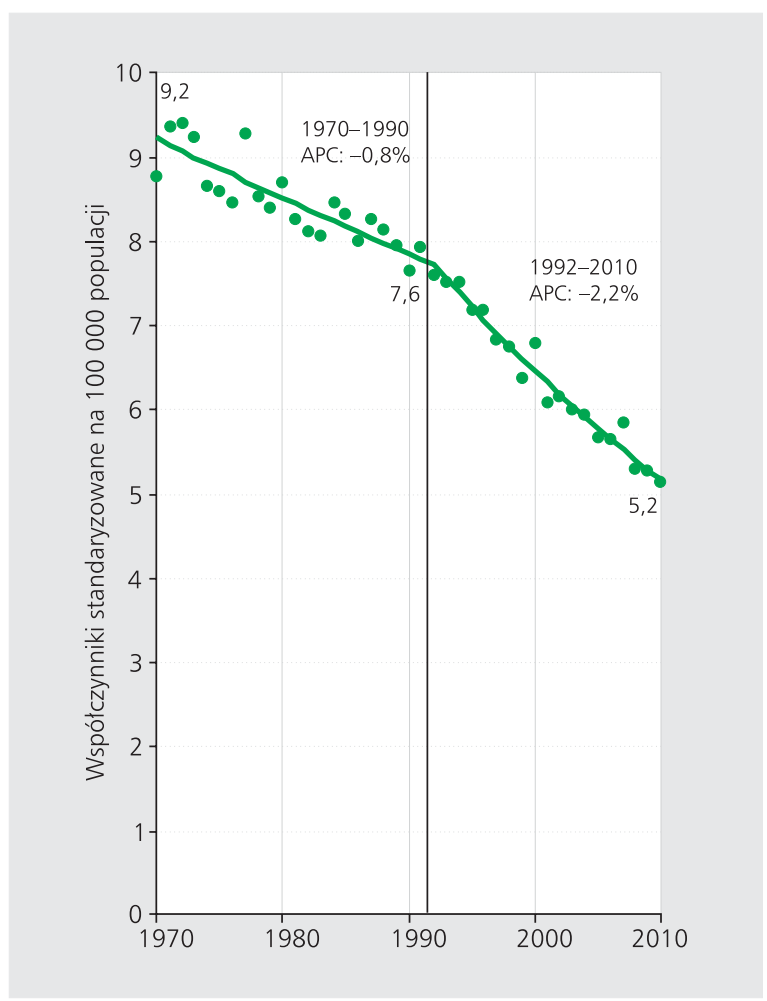

Rycina 3. Umieralność z powodu nowotworów szyjki macicy w Polsce, 0+, 1970-2010. APC (annual percent change) - roczna zmiana procentowa

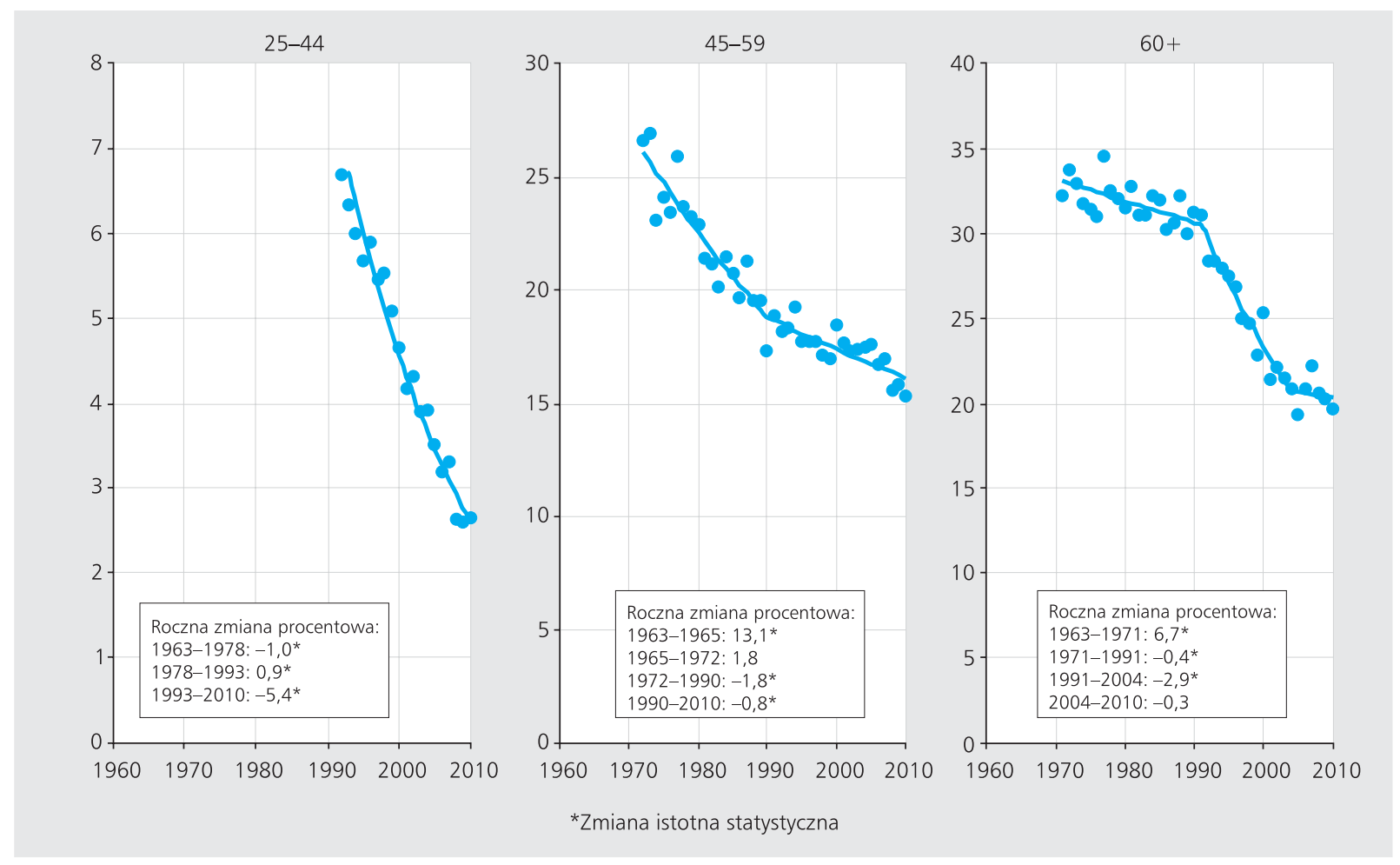

Rycina 4. Umieralność na raka szyjki macicy w Polsce, 1970-2010. Współczynniki standaryzowane zostały obliczone w oparciu o standardową populację świata 


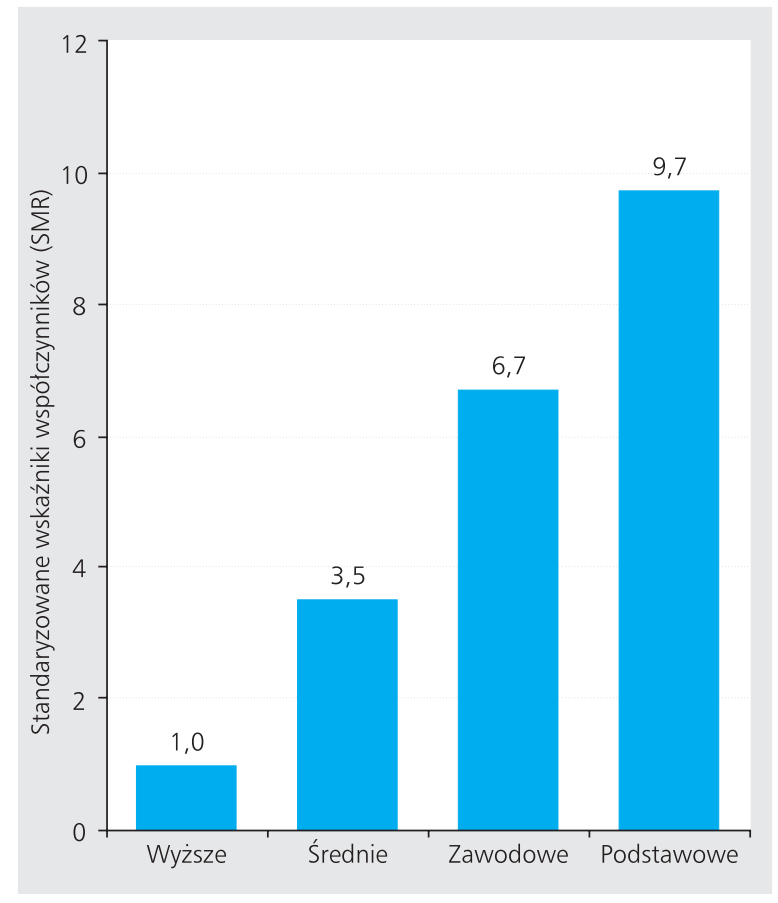

Rycina 5. Umieralność na nowotwory szyjki macicy w Polsce według wykształcenia, kobiety w wieku 20-44 lat, 2002

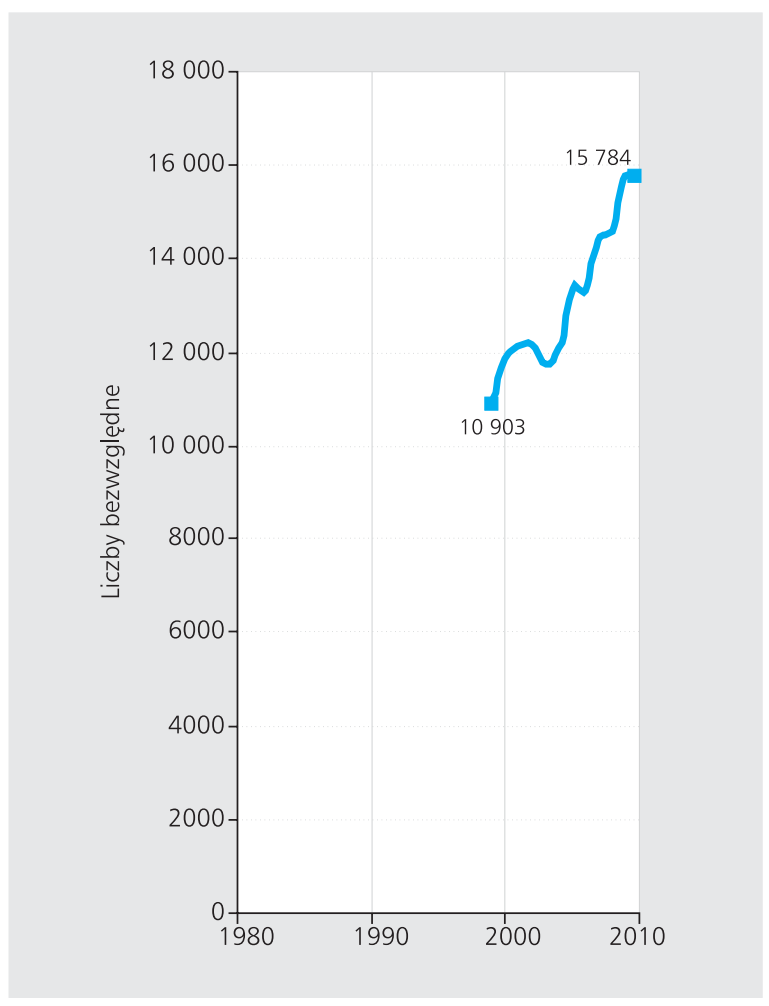

Rycina 6. Rozpoznane (zachorowalność) nowotwory złośliwe piersi w Polsce, kobiety, 1999-2010

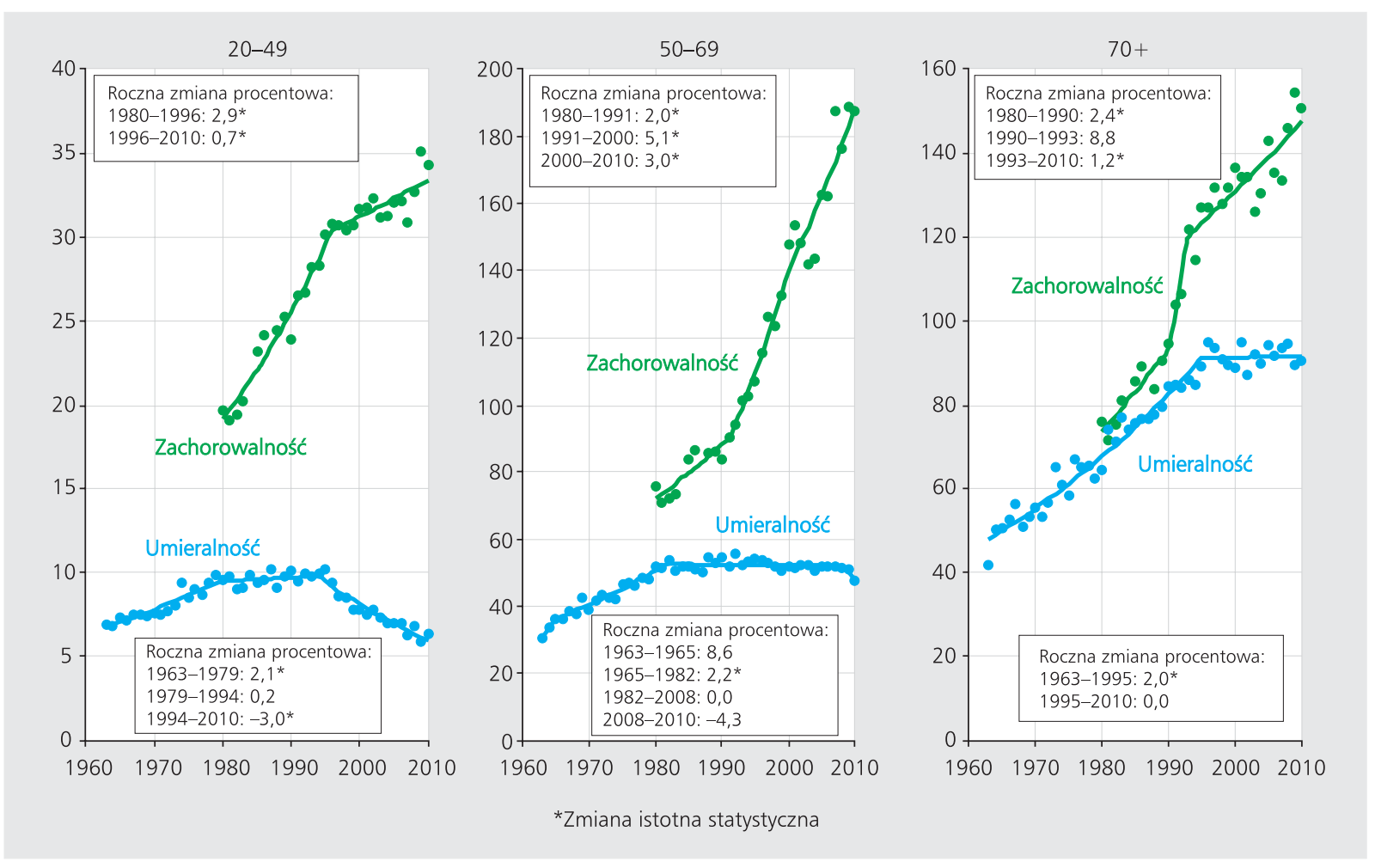

Rycina 7. Zachorowalność i umieralność na raka piersi w Polsce, 1963-2010. Współczynniki standaryzowane zostały obliczone w oparciu o standardową populację świata 


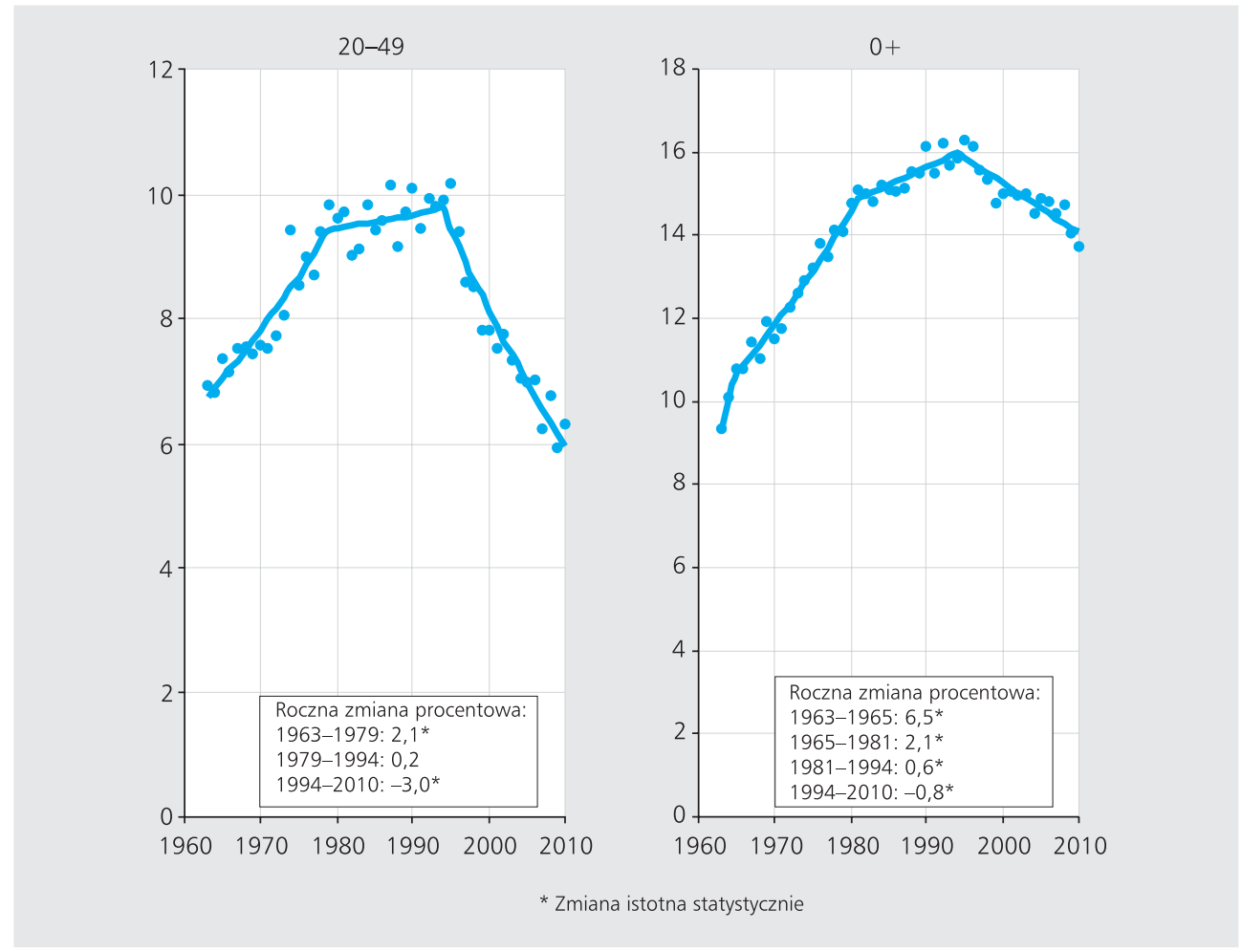

Rycina 8. Umieralność na raka piersi w Polsce, 1963-2010. Współczynniki standaryzowane zostały obliczone w oparciu o standardową populację świata

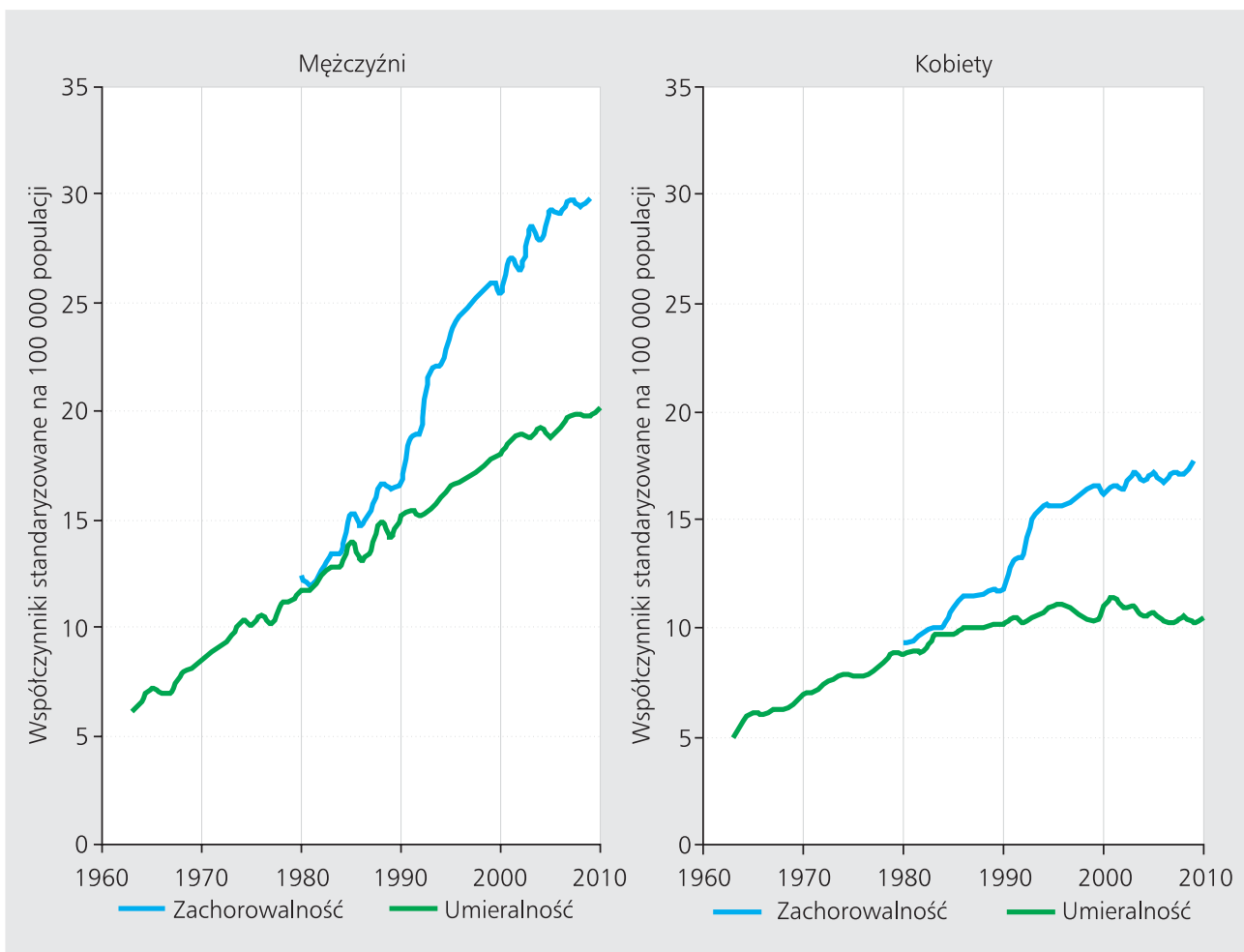

Rycina 9. Zachorowalność i umieralność na nowotwory jelita grubego w Polsce, 1963-2010. Współczynniki standardyzowane zostały obliczone w oparciu o standardową populację świata 
(np. rozejście się trendów czasowych zachorowalności i umieralności, zdają się wskazywać na rosnące zjawisko nadrozpoznawalności6.

3. Realizacja programu wczesnej diagnostyki nowotworów jelita grubego znajduje się we wczesnym etapie przygotowania do jego populacyjnej realizacji. Dokonano ogromnego postępu w szkoleniu lekarzy i personelu medycznego. Ośrodki specjalistyczne wyposażono w niezbędny sprzęt. Przeprowadzono jego pilotowe wdrożenie w wielu regionach Polski. Prowadzone w Polsce prace w tym zakresie uzyskały bardzo pozytywny odbiór ze strony międzynarodowego środowiska naukowego ${ }^{7}$. Pełen program skryningowy $w$ kierunku jelita grubego $w$ skali populacyjnej wymaga jednak uruchomienia znacznie większych środków i powołania organizacji do jego stałej realizacji (co zawarte jest w propozycji powołania Narodowego Instytutu Onkologii i Hematologii w Warszawie). Dopiero taki program i jego realizacja mogą doprowadzić także w Polsce do zmniejszenia umieralności z powodu nowotworów jelita grubego (ryc. 9).

Reasumując, po 8 latach funkcjonowania NPZChN doprowadził do głębokich zmian w funkcjonowaniu wczesnej diagnostyki i leczenia nowotworowego w tych lokalizacjach gdzie jest to możliwe. Jego realizacja, co oczywiste, musi być dalej pogłębiana i wymaga także budowania kompetencji społeczeństwa (walka zanalfabetyzmem w zakresie nowotworów) orazjego gotowości do uczestniczenia w programie, a nie tylko rozbudowy infrastruktury. Program musi być konsekwentnie realizowany (co nie znaczy, że nie wymaga także fundamentalnych zmian wynikających z postępu wiedzy medycznej) przez następne dziesięciolecia. Dlatego też istnieją ważne przyczyny dla których Centrum Onkologii i sieć regionalnych centrów onkologii muszą być ważnymi uczestnikami tworzenia kolejnego planu walki rakiem na lata 2016+. Nowy program nie może być zlepkiem koncepcji wynikającym z nacisków różnych instytucji i grup, ani być tworzony pod wpływem emocji, ale musi wynikać z medycyny opartej na dowodach (science-and-evidence based) i rachunku ekonomicznym. Program musi także być realizowany w taki sposób, aby uwzględniał najbardziej zagrożonych chorobami nowotworowymi (to jest gorzej wykształconych i sytuowanych). Jego realizacja musi być transparentna, programowana i kontrolowana przez niezależne ciała zawodowe, społeczne i polityczne.

\section{Prof. zw. dr hab. n. med. Witold A. Zatoński}

Zakład Epidemiologii i Prewencji Nowotworów Centrum Onkologii — Instytut im. Marii Skłodowskiej-Curie ul. Roentgena 5, 02-781 Warszawa e-mail:canepid@coi.waw.pl

\footnotetext{
${ }^{6}$ Nadrozpoznawalność - Rozpoznanie guzów nowotworowych, które nigdy nie doprowadziłyby do wystąpienia objawów klinicznych ('The detection of cancer that would never have become clinically evident'). Problem nadrozpoznawalności dotyczy wszystkich rozwiniętych krajów które prowadzą populacyjny skryning.

${ }^{7}$ Patrz publikacje w wiodących czasopismach lekarskich: Reguła J. i wsp., Colonoscopy in Colorectal Cencer Screening for Detection of Advanced Neoplasia NEngl J Med 2006; 335: 18663-72; Kamiński MF, Reguła J, Kraszewska E, Polkowski M, Wojciechowska U, Didkowska J, Zwierko M, Rupiński M, Nowacki MP, Butruk E, Quality Indicators for Colonoscopy and the Risk of Interval Cancer. N Engl J Med 2010; 362: 1795-1803.
} 